\title{
Reclaiming Radicalism: Discursive Wars and the Left
}

\author{
Giorgos Charalambous
}

\author{
University of Nicosia, Nicosia, Cyprus, charalambous.gi@unic.ac.cy, \\ https://www.unic.ac.cy/charalambous-giorgos/
}

\begin{abstract}
The aim of this article is to identify and discuss a number of labels that have been increasingly used to describe, categorise and study the contemporary radical left - the movements and parties of the socialist tradition and its contemporary derivatives - pointing to the deeply political implications of these trends. More specifically, 'extremism', 'populism' and 'nationalism' as signifiers of what left radicalism looks like are scrutinised in terms of both the political logic and the historical background behind their use, and the challenges they raise for emancipatory, progressive politics. A plea for recasting contemporary social and political struggles for equality and rights is subsequently articulated, the central conviction advanced being terminological: the left's struggles today must rise above the verbal smoke of the predominant discourse about this political space. It is a key task to appropriately qualify those terms that taint contemporary radicals with colours which do not represent them or fall far short from defining them. Put simply, if the radical left is to succeed electorally and channel its vision into society effectively it needs to reclaim its chief identity trait in the public sphere: left radicalism itself. Reclaiming radicalism entails a number of strategic tasks. These are laid out in terms of imperative discursive articulations, which are, however, paralleled by particular political actions on the ground that can either confirm or undermine any terminological claims.
\end{abstract}

Keywords: radical left, discourse, populism, extremism, nationalism, political communication

Acknowledgement: The author would like to thank Gregoris loannou, the journal's two reviewers and the editor for comments which have improved the article.

\section{Introduction: The Politics of Terminology}

In the past twenty years a number of concepts and labels have been used and misused to describe radical left identities; specifically, 'extremism', 'populism' or an 'illiberal' heritage, and 'nationalism'. These terms have become very common as descriptors of radical agency in journalistic and popular discourse; they are used by centrist and conservative politicians and they are also entrenched in academia. The reconstruction of the radical left's identity by politicians, journalists and scholars away from its historical characteristics and into a realm of concepts that blur its uniqueness as an egalitarian and democratic movement certainly does not work in its favour. When exposed to analytical frames that treat the left as part of a much larger political group whose defining features are not those of the radical left in relation to all the rest, radical left forces draw polemic more easily and are less distinguishable in the public sphere, or stand out for the wrong reasons.

The aim of this article is to identify and discuss a number of labels used increasingly to describe, categorise and study the contemporary radical left - the movements and parties of the socialist tradition. While pointing to the implications of these trends, a plea for recasting contemporary social and political struggles for 
equality and rights is subsequently articulated. The central conviction advanced is terminological: the left's struggles today must rise above the verbal smoke of the predominant discourse about this political space. It is a key task to appropriately qualify those terms that taint contemporary radicals with colours which do not represent them, or fall far short from defining them. Put simply, if the radical left is to succeed electorally and effectively channel its vision into society it needs to reclaim its chief identity trait in the public sphere: left radicalism itself. That is, opposite other social and political forces, left radicalism must pursue the signification and defence of its chief properties: equality and the call for major redistribution; roots and branch change; democracy and overcoming its liberal capitalist deficiencies; internationalism and the identification of a globality in structurally rooted oppression (see March and Mudde 2005).

This article follows that there are material ramifications for radical movements to the systemic reconstruction of the left. Its portrayal exerts actual pressure which may weaken movements. This can happen through the alienation of potential or actual voters, and through the disorientation of left forces away from radical positions as a form of co-optation to entertain allegations. These two tendencies would also feed into each other. Through cues that misconstrue party identity, masses of voters with views that are ideologically incongruent to the left may alter its internal political dynamics. Given this, they can facilitate the mutation of the left's role in society as a historical movement.

Especially in today's context, these ramifications must be accentuated, as there is already an existing penetration of the contemporary left by postmodern relativism, following the severe setbacks of Marxism as theory, certainty and a unifying pole for radicals. Dominant liberal perceptions have pushed the left away from its historical roots, because, among other things, they deny it a revolutionary subject and the feasibility of an alternative ${ }^{1}$. By implication the main distinctions of the left-right divide and the properties of the radical left today are already less rooted in class voting and between pro-and-anti-capitalism. Since around the 1960s, a two-dimensional space has structured political conflict in the West: an economic dimension cross-cutting the dimension of identity politics (tradition, authority, nationalism). In this complexion, lines of separation between distinct and even markedly different spaces can be blurred, specifically if positions on only one dimension of conflict are reported or given more attention, or the relationship between dimensions is turned and twisted by systemic discourse.

The terminology applied to political movements constitutes a central concern for contemporary radical strategy. It affects citizen as well as militant perceptions about the aims and means of struggle by the socialist movement and its contemporary derivatives. In short, terminology is itself a politics because in every socio-economic system discursive wars about politics reflect conflict in interpretations, ideas and material interests. Terminology is especially important in the context of relatively new competitors for radical left parties today. The contemporary radical left, unlike most of its post-war predecessors, has been confronted by a resurgent far right, which has become a key competitor attracting part of the blue-collar working-class vote. Between the early 1980 s and the late 2010 s these parties have more than doubled

${ }^{1}$ For the crisis of Marxism and the significance of the 1960s and 1970s, see Kouvelakis (2020) and Meiksins-Wood (1986). For the "dictatorship of no alternatives", see Unger (2009). 
their vote share in Europe, while the broader phenomenon of rising right-wing extremism has taken up a global presence.

The rise of the far right has been widely documented, so here it will suffice to note that it poses a challenge for the left largely in the context of very high electoral volatility, a decline in partisan identifications across the board and the significantly weaker status and capacity of trade unions. More particularly, the increasing importance of working-class constituencies among far right forces raises questions that are most relevant to the left's identity and politics. A 'proletarisation' of far right party voters was reported for the 1990s across various European countries, leading to the eventual predominance of working-class votes among the far right social milieu. ${ }^{2}$ Without a strong government social policy, something virtually impossible under conditions of permanent austerity, welfare chauvinism as a sort of pseudosocialism obtains electoral force. Welfare chauvinism targeting immigrants constitutes a feature and outcome of welfare retrenchment in the context of the broader neoliberal restructuring of the welfare state (see Keskinen, Norocel and Jørgensen 2016; Mondon 2014).

Terminological claims are intermediated by concrete politics. For some decades now radical left parties have found themselves voting in parliament or advocating policy positions similar to those of the far right. In France, this was the case in 2005 at the occasion of the national referendum on the ratification of the European Constitution, where both the radical left and the extreme right mobilised against ratification, obviously for different reasons. In many countries the far left and the far right parties have both been anti-austerity actors; in Greece and Cyprus, ELAM (National Popular Front) and Golden Dawn took an anti-bailout stance and voiced anti-austerity discourse (Charalambous and Christoforou 2018). In Scandinavian countries, social democratic ideas are combined by parties such as the Sweden Democrats (SD) or the Danish People's Party (DPP), which blend statism with a xenophobic nativist component, which in turn leads them to vote inside parliament like the left on various aspects of budgetary and welfare policy, although they view immigrants and other minorities as 'scroungers'.

At the same time, party systems have become increasingly fragmented, making it difficult to ingrain the left-right as a bi-polarity among citizens, especially in the context of postmodernism having undermined it for several decades now. Many militants and leaders of the extreme right as well as parties of other positions claim to operate beyond and above the left-right divide, arguing that it is obsolete, which is of course not the case ${ }^{3}$. Events that have shaped contemporary party competition and political conflict are driven by social realignments. New dividing lines were drawn into shape during neoliberal globalisation and its associated forms of regional economic integration, between the so called 'losers' and 'winners' of these processes. Neoliberalism led to a 'hollowing of democracy in the West', which in turn spurned political disengagement at the same time as extra-institutional forms of protest (Mair 2013). With regard to the effect of conflating distinct spaces, radical left parties carry some of the blame. Their failures in office on various occasions since the 1990s disappointed voters, and more generally contributed to perceptions of the Left as a force of the status quo. This in turn can feed the growth of the extreme right, which

${ }^{2}$ For empirical studies, see Oesch (2008) and Rydgren (2013).

${ }^{3}$ For rigorous empirical investigations that validate the sustainability of the left-right divide, see Rosas and Ferreira (2013: Section V). 
can claim more easily a radical identity and sell the narrative of a sold-out Left, one 'like all the rest'.

The rest of this article engages with the discursive wars at play concerning the radical left and its politics during the past twenty years or so. It seeks to explain the chief instances of conceptual blurring and misnaming and how these translate into political challenges. Subsequently, it is argued that overcoming these challenges is a necessary justification of emancipatory identities and that this entails a number of strategic tasks. These are laid out in terms of imperative discursive articulations. Discursive strategies, however, are paralleled by particular on-the-ground political actions that either confirm or undermine any terminological claims. Before concluding, therefore, ontology, the very practice of radical left politics, is considered. Illuminating how political behaviour itself impinges on any attempt towards epistemological counter-hegemony, the article suggests the further production of theory for unveiling tensions and complementarities between the two.

\section{The Radical Left in a Sea of Names}

\subsection{An Extreme Left?}

Above we were reminded that the far right poses a serious challenge for the left and class politics. But the problem is not only that the far right is today, unlike the earlier post-WWII period, one of the chief political competitors of radicals in elections and in the streets. Part of the challenge for radicals is the intellectual energy invested in popularising a 'two extremes' thesis, utilised to polemicise both the radical left and the radical right by equalising them as inimical to democracy, as irrational and populist, as extremists and opponents to the enlightening and necessary process of European integration and globalisation. The first problem of changing party systems is compounded by a second: while in competition, the radical left and the radical right are often treated as alike. Broadly speaking, a 'two-extremes' thesis has developed, formulating and testing assumptions about the commonalities and differences between radical left and radical right parties. For example, because welfare chauvinism also effectively opposes the neoliberal "lean state", as a framework for social and welfare policy (Sears 1999, 1-5), many of these parties have claimed an anti-neoliberal stance; and many commentators have fallen for it. Research in political psychology has invested heavily on studying cognitive behavioural affinities between the supporters of non-centrist ideologies. Some studies go as far as suggesting psychological distress as a driver of espousing 'extremist' ideologies, both left-wing and right-wing, because personality disorders are assumed to stimulate the adoption of an extreme ideological outlook, which is in turn seen as expressing 'simplistic, black-white perceptions of the social world' (van Prooijen and Krouwel 2019, 159).

The equalisation of the two poles in the political spectrum underlying most contemporary political analyses working with the 'two extremes', whether these point to more or fewer differences, is catalysed by the definitional approaches that have predominated in the study of neo-fascism and contemporary forms of right-wing extremism. In much of political science scholarship, and the study of party politics, the far right space is defined as 'radical right parties' and 'populist radical right parties', while 'neo-fascist' or 'extremist' parties are considered to be for the most part extra-parliamentary fringe groups ${ }^{4}$. Three claims are at play in this framing:

\footnotetext{
${ }^{4}$ For an indicative summary of these trends, see Golder (2016).
} 
radicalism can be conservative, the radical right is not extreme and extremists are not typically inside parliament. All three of these underlying convictions that turn ideas into definitional vocabulary damage the left's case; both the view that extremism and the mainstream right coalesce and are historically enmeshed (see Kallis 2015) and the argument that true radicalism can only be progressive, unlike the situation on the right where radicalism translates de facto into ultra-conservatism, authoritarianism and extremism.

Unsurprisingly, Google's search engine generates as a first result for 'extremism' the following Wikipedia lines: "Political agendas perceived as extremist often include those from the far-left politics or far-right politics as well as radicalism, reactionism, fundamentalism and fanaticism". Obviously, under no circumstances is the contemporary radical left an extremist force; it is the exact opposite, an agent of progress and development, with all the essence of its internal deliberations, theorybuilding, strategic debates and cultural resonance. Yet in the context of these and related discussions, 'left-wing extremism' is not an uncommon term. This is so, certainly in political discourse by the left's enemies which aim to discredit it, but also in academic studies (see March 2008; March and Mudde 2005; Backes and Moreau 2008).

In a seminal definition of the radical left, Luke March and Cas Mudde distinguish between the radical and the extreme left, arguing that extremism is an "ideological and practical opposition to the values and practices of democracy, either as it exists in a particular system, or as a system, which may, but does not necessarily, involve a propensity to violence". The net is cast as wide as possible, only to subsequently identify extremism as anti-democratic per se, not as simply anti-liberal democratic (March and Mudde 2005, 24-25). But it is also still insisted that "extreme left parties [...] have far greater hostility to liberal democracy [...and] define anti-capitalism much more strictly" than radical left parties (March 2008, 3). These reflections translate into categorising most communist and Trotskyist parties in Western Europe and unreformed communist successor parties in Eastern Europe as 'extreme left'. In other words, the anti-capitalist left is the extreme left, whereas the reformist, antineoliberal left is radical. It seems that part of the equation in labelling anti-capitalism as extreme is to first identify free enterprise and profit-driven accumulation with democracy. All these narratives reflect the Aristotelian tradition, whereby

the centre is at the same time a point of balance between too much and too little. In it, traits that are fully expressed by the extremes come to the fore in a milder form. The centre, often the metaphor for equilibrium and scales, embodies the principle of moderation. In the doctrine of virtues, the centre stands for morally appropriate behaviour that neither exaggerates nor understates; it neither extends far beyond that which is imperative nor remains far behind. Virtuous behaviour is the condition for a telos which the individual is capable of reaching, both with and within the society of the state: a moderate and virtuous life allows for eudaimonia, the unfolding of human happiness (Backes 2010, 177).

The problem arises when modern transpositions of what constitutes virtue, and by extension virtuous politics or extremism, are taken to deny virtue to resistance and cast resistance as inappropriate for eudemonia. It is also problematic to equate extremism as 'opposition to constitutional democracy and the rule of law' with 'extreme measures' as transformative visions of change and uncivil forms of 
resistance. While the former definition describes the quality or state of being extreme, the latter refers to the advocating of radical views but not necessarily an antidemocratic outlook, which is engendered in the former definition.

To relativise this idea of extremism one can cast it as something transcending the classical left-right continuum, or not to be found only on the poles of a political spectrum. One should not forget, after all, the analysis of fascism as the result of a base built on the extremism of the centre. ${ }^{5}$ More recently, Tariq Ali's (2015) analysis of the "extreme centre" reveals a political space which, although nominally centrist, rests upon a politics of full compliance with neoliberal doctrine. Ali captures the consensus over which all major political parties of the Europe and the USA have converged: a dangerous politics tailored to the needs of the market and based on the material pursuit of self-enrichment by politicians $(2015,42-53)$ : that is, the very opposite of politics for the public good, where given minimal political differences, 'the symbiosis between power and money has almost everywhere reached unbelievable extremes' (Ali 2015, 3).

Indeed, the West's extremities are not few in the sense of violating civil and political rights or inflicting direct or indirect harm on humans. They range from state repression and police brutality, to foreign military intervention resulting in the massscale loss of human lives, to crimes of war more generally, to the uprooting of indigenous populations in pursuit of new markets, to deeply entrenched corruption and patronage practices in several countries, to condoning slave-like working conditions for subaltern groups, to pushbacks of immigrants on national waters, including young children, to the mainstreaming of far right agendas; the list is long and painful.

Given that these are features of a new neoliberal extremism permeating both the centre-left and the centre-right, and also condoned through hundreds of mainstream media outlets, then for several decades now these spaces in Europe have been much more extremist than the radical left. A plethora of historical and contemporary extremities have been committed by both the centre-left and the centre-right; hence, the 'extreme centre', nominally centrist but substantively extremist. If political families' ideologies are measured through manifesto pledges, as commonly happens from a positional perspective, the ways in which pledges are fulfilled or not fulfilled in the making of everyday individual, political and government decisions cannot be captured, and this overlooks much of the extremism in mainstream spaces.

Part of the accusation about extremism concerns mobilisation tactics and more specifically violent or uncivil acts. In the US, from Portland's Antifa community to the Dakota Pipelines, radicals have been accused of aggressive and violent behaviour. Notably, Noam Chomsky criticised Antifa tactics in the US, such as physically preventing members of far right groups to express their views, as deeply counterproductive because, among other things, they may elicit an extremist response by the state through, for example, the initiation of 'anti-terrorism' programmes of political surveillance. As much as Chomsky is not against, but rather very much for Antifa groups, he was criticised for this view. One argument is that tactics are designed given a particular viewpoint. Many anti-fascists, and indeed the historical left, have seen fascism as a serious political opponent largely generated from capitalism, not

5 This point was famously shown by Lipset (1958). His argument was that, unlike the prevailing understandings of his time, "extremist ideologies and groups can be classified and analysed in the same terms as democratic groups, i.e. right, left, and centre" (347). 
merely a difference of opinion. Thus, as Michael Bray explains, anti-fascists understand their politics

as a struggle rather than something which can sit within a liberal rights framework. Some members of the movement say no free speech for fascists because historically fascism has invalidated its legitimacy in the public sphere - it has shown itself to be violent and genocidal (quoted in Oppenheim 2017).

Beyond Antifa and into the whole spectrum of violent and uncivil resistance, much intensified today, this should not be conceived (at least not always) as irrational, even if sometimes tactically flawed. On the contrary, "non-institutional collective actions are not irrational; instead their departure from the proper pathways of politics reflects the deficiency of systemic channels in connecting citizens to the state, and is, if anything, eminently rational" (Seferiades and Johnston 2016, 4). If conflict "involves the - more or less - institutionalised relationship between contentious claimants and the state (or, more broadly, the authorities)" (Wievorka 2009, quoted in Seferiades and Johnston 2016,5 ), then violence is the means resorted to in the absence of meaningful space for institutionalised mobilisations: as Michel Wieviorka puts it, "violence is an expression of the exhaustion of conflict" (quoted in Seferiades and Johnston 2016, 5). Violence then defies institutionalised 'conflict' because grievances and claims cannot extract concessions by elites (see also Hobsbawm 2007, 234). This explains why terrorism and the revolutionary left first developed in states where protesters lacked access to legitimate politicalparticipation and clandestinity or insurrection was their only means of mobilisation and resistance (Seferiades and Johnston 2016, 5-7; Vössing 2011; Tarrow 1998, 95). Violence overall, including its relation with the radical left, cannot be separated from the context of global neoliberal system deficiencies. These generate more or less universal patterns of disruptive and unlawful behaviour. In the age of authoritarian neoliberalism, violence is politics in a system otherwise insulated from the political. ${ }^{6}$

What characterises the crashing majority of the radical left, Antifa groups only partly excepted, is not violence as the unthinking, fanatical, hot-headed violation of rights or physical harm to others. It is more a case of civil disobedience or, more specifically, uncivil resistance and the civil disobedience this entails; the duty to disobey authority if the latter is too coercive or unjust. Pursuing this through various activities, ranging from squatting, to Antifa street fighting, to peaceful refusal to be evicted, to solidarity-based unlawful action, has been a common procedure of mobilisation and resistance among activists, especially during periods of heightened working-class misery. In light of the civil disobedience argument that when authority is extremely oppressive extreme counter-measures are required and arise from a duty of resistance, the left's 'extremism' is a consequence of its diagnosis that politics are oppressive and anti-democratic to the extent that an uncivil response is legitimate and strategically strong. Resort to 'extremism' is a conscious choice that derives from actors' conviction that disobedience is necessary and that labelling it as extremist is a deeply political issue to begin with, entrenched in the battle over the current status quo. Certainly, such a conviction fluctuates in strength amidst changing circumstances, both within the left and in society at large. Today, at a time of huge inequalities across and within countries and the mainstreaming of the far right, this conviction is perhaps more 'historically legitimated' from the critical observer's point of view than earlier.

\footnotetext{
${ }^{6}$ For the main (new) features of authoritarian, neoliberal structures, see Bruff (2014).
} 


\subsection{A Nationalist Left?}

Radicals utilised nationalism "as a key player in the politics of modernity", "developed in association with ideas of popular sovereignty and mass democracy bound up with ideas of the self-determination of a given people, defined by shared history and common political rights" (Schwarzmantel 2012, 148). The left has thus often rallied on platforms embracing nationalism as a civic concept evoking democracy and selfdetermination whereby the nation is the framework for achieving social progress. This is not to say, however, that the alliances of Marxism and socialism with nationalism have not been problematic; indeed often socialism has taken "a "back seat' in the coupling" $(2012,150)$. Concurrently, "the difficulty which Marxist or Marxist-inspired theories have had in grasping the complexities and enduring appeal of nationalism" (Schwarzmantel 2012, 145) have led to disagreements, which have always manifested themselves into diverging political positions: from Lenin's disagreements with Rosa Luxemburg on Poland in the early 20th century to the Catalan question in Spain in 2018 and the balancing acts of Spanish politicians and parties on the left in regard to how the issue plays out in the institutionalised public realm.

The European radical left has tended to deconstruct national identity or any form of ethnic claim as an 'imagined community', with nationalism engendering nations and "not the other way around". In this vein, tradition and national sentiment has been invented by the profit-seeking drivers of capitalism and the formative processes of the nation-state (Anderson 2006; Gellner 1983; Hobsbawm and Ranger 1983). At the same time, while acknowledging nationalist claims as real political grievances manifesting out of imperialist oppression, the left is challenged by the claim that "ethnic myths, narratives, beliefs and symbols" which "often predate the modern advent of nationalism" cannot easily disappear (Conversi 2017; see Smith 1999; 1995). Moreover, this is the epoch of heightened nationalism due to the effects of neoliberal globalisation; the national element in various forms has been on the rise in backlash to the processes pushing economic integration forward. From a strategic point of view, many on the left acknowledge that simply dismissing and deconstructing nationalism could "consign the most powerful ideology in modern history" and today, thus a key political resource for mobilisation and resistance, to political enemies (Conversi 2017). It would also ignore that even in the era of globalisation, the reproduction of capital, income distribution and economic elite formation take place in the frame of the (national) state. The state also remains a relevant reference for progressive politics because the legal grounding of labour relations, welfare provisions, military practice and institutional democratic arrangements remain primarily nationally based. Moreover, if we accept that the EU after Maastricht has institutionalised a technocratic, neoliberal, non-transparent, unequally beneficial and fortress-like governance, then national sovereignty can at once and simultaneously constitute a fight against multiple enemies (that is, policy directions).

The Scottish referendum and developments in Catalonia have re-revealed social movements and parties that are (and have historically been) both nationalist and leftwing. How are we to classify regionalist parties in Catalonia or Scotland, or Northern Ireland, or Galicia or Brittany, combining claims to self-determination with socialist principles? Sinn Fein's ideological profile in the Republic of Ireland has divided academics and activists over its radicalism and its socialism. These peripheral nationalisms and the ways they shape the political agenda are a topic towards which the radical left in Europe again remains divided. Many on the Spanish and European 
left have voiced suspicion at the rise of Catalan separatism, seeing it as a chiefly nationalist phenomenon, which can be and is capitalised upon by the ruling classes to divide the economically oppressed (see Vilallonga 2015).

Even though the radical left since Lenin is sympathetic to the right of selfdetermination, many activists distrust both the leadership of separatist forces and its regional coalition with centrist or right-wing nationalists, and the potential effects of secessionism on the national left and society more broadly (2015). Others remind us that the Catalan question and along with it the Kurdish, Corsican, Scottish and Palestinian movements must be framed not as national questions, ones which concern above all the sacredness of the nation state, but rather as questions of democracy, regarding above all the democratic right to self-defence of the minority: practically, its right to separation or secession. What remains of political essence across all cases is the civic component of nationalism, which can blend with socialism. The people of a nation-state are seen as such by the left not due to ethnic claims of identity but for being a political community. Simultaneously, there is an emphasis on the need for forms of international solidarity as resistance to global capitalism. It is not surprising then that many pro-independence Catalan activists are engaged in solidarity struggles with immigrants and political refugees or in the antihouse-eviction movements. Catalan claims to secession, Catalan culture and ethnicity among radical sections of the populace do not negate, but rather coexist with their internationalist sympathies.

Given that discussions over Scotland or Catalonia take place in the very context of discursive slippage and political misnomers, a doctrinal stance on either case in favour of or against secession can be avoided as much as it can be excused. If radicals are divided over today's political dilemmas posed by sub-national identities in Europe, and given that such divisions are historical, then at least these divisions have to be approached and if possible resolved, not as independent of egalitarian and socialist questions, but solely in connection to them. The conservative right and extreme right parties in the 20th century predominate in terms of identification with and use of nationalism, although it was on left-wing ground that nationalism and the advent of the nation state developed in the late 18th and the 19th century (Hobsbawm 1996, 38-47). The national issue cannot be neglected if the left is to semantically associate (or dissociate) itself with (from) nationalism in ways that are in its favour. Nationalism as a label and strategy surely works negatively in the sense of recalling the far right and enabling easier identifications of the left with populism, extremism, illiberalism or particularism and thus the effective contradiction of internationalism. Still, the left needs a case for nationalism because its struggles (and politics tout court) have always de facto included an evolving national question, because self-determination is a central part of world affairs and is likely to stay as such. Subsequently, the sovereignist left, or the argument of sovereignty, national and by extension popular, must be understood as embedded in the socialismnationalism nexus, with politically determinate outcomes as to which side will predominate in the fusion.

Indeed, how progressive nationalism can be is a question of context. Consider divided Cyprus, where Greek and Turkish nationalism have systematically been the breeding ground of militaristic, corrupt and religious politics, and more broadly the chief obstacle to bi-communal peace on the island. Contrast Cyprus with Scotland in a Britain ruled for a prolonged period of time by the Conservative party in a neoliberal direction. Contrast Cyprus also with the case of the Catalan secessionist left after the authoritarian and harsh response of the Spanish state to the dissenting Catalan 
politicians who upheld the 2017 referendum result. Progressive attitudes and national, regional, local, or indigenous identities mix especially where the latter arise in a context of ethnic and other conflicts, or disagreement over sub-national jurisdictional claims. But the national context itself is of utmost importance as to the potential of nationalism or ethnocentrism to contribute to social progress or translate into a radical political demand with potential for change not possible in the current state of affairs.

Political labels and, even more so, academic concepts can still be damaging for the left if the link between ideas and the language they condition is not clarified. Such would be the case of the recent defence of sovereignty among many radical left parties in southern Europe, faced with austerity-driven bail-out programmes. The quintessence of the phenomenon of diminished sovereignty - especially in the Eurozone context - that the radical left identifies as a problem is the lack of accountability of those implementing economic policies. This translates into an inherently illegitimate governance. From this angle, national sovereignty on the radical left is popular sovereignty because only national governments can be accountable to the people, who in turn through them can exercise sovereign power. Therefore, if there is not a people bounded nationally through common territory, there is no popular sovereignty. Following this, repossessing the national state and the national border as economic devices is a defence mechanism against neoliberalism an edifice to counteract its negative consequences (see Kallis 2018, 301). Saying that the chief idea behind calls for 'economic sovereignty' is social justice may sound unnecessary, but it is not. If 'economic sovereignty' is not explained in correspondence to understandings of what constitutes the popular, as well as up-todate theories of imperialism, its associated discourse can more easily be misinterpreted. It would then signal an ethnic or nativist, or isolationist, or vaguely 'populist' attachment in opposition to prevailing notions of globalisation and integration. As a pejorative, the same thing is framed as 'economic nationalism', a term utilised widely by liberal commentators and academics (see Pickel 2003).

Nationalism is, like populism, located at the intersection of language and ideas, and has had its imprint on the left since the very beginning. As things are, nationalism is today on the rise, ruling the world across countries and continents. This twofold realisation should direct our interest onto how radical reflections are framed with a national perspective, rather than merely whether they should or not. In the public sphere of the information society, there is conflict over framings of the egalitarian opposite the national, and whether these can advance or constrain radical political struggles. In the final analysis, what should interest the global left is how to connect nationalism with socialism and claim a radical left position in struggles where the two are associated to begin with; as in secessionist and regionalist spaces or in opposition to Eurozone-rooted austerity.

At the same time, and above all, disconnecting the left from nationalism as ethnocentrism is of absolute importance if its fundamental divergences from nationalism as overarching ideology, as for the conservative and far right, are to be defended. There is a need to explain that nationally-based claims in politics can be progressive; at least that they are not always conservative in nature, but not because national attachment (territorial or ethnic) is endogenously superior to globalism. Rather, because global, radical and humanistic values and strategies to mobilisation and resistance can sometimes be disseminated through nationally sovereign action in a world defined by imperialist dogmas and contradictions. Otherwise, if sovereign claims are not communicated with an internationalist outlook, they can be accused of 
particularism. In order to reconcile local, national and global claims to politics, a way forward would be to propagate a strategy of "shared sovereignties", as in parts of the Catalan municipal and secessionist movements (Agustín 2020, 70). Through defending multilevel or 'relative' sovereignty, the region, the nation-state or the entire planet would not be approached as exclusive arenas of either struggle or legitimacy. Rather, their significance and coexistence would more clearly be conveyed as shifting and taking shape depending on issue, historical period and political setting.

\subsection{A Populist Radical Left?}

At core, populism is the discursive schema between a people: the ordinary citizens opposite a corrupt elite or establishment. The people can either be exclusive or inclusive, emancipatory or reactionary, depending on how the frames of populism attach to core ideologies of the left or right (see Mudde 2004). Based largely on the work of Ernesto Laclau, various radical left parties have been inspired by a discursive strategy of constructing the people as a counter-hegemonic force - notably Podemos and France Insoumise. Post-crisis social movements, especially given the digital revolution on which they have capitalised, are also seen as embracing populism; and with it, citizenism, sovereignty, autonomy, inclusivity and horizontality (see Gerbaudo 2017; Katsambekis and Kioupkiolis 2019, xi-xii). Some authors call attention to leftwing populism as a force which disfigures democracy, with a personalistic appeal embodied by a charismatic and powerful leadership voicing demagogic discourse (see Mudde 2004). Many comparativists also treat the radical left parties as 'antiestablishment' actors who are critical towards liberal democracy or, in some cases, even contest the very idea of democracy, demanding an in-depth transformation of the entire democratic system (Abedi 2009; Backes and Moreau 2008; March and Mudde 2005; Schedler 1996). Populism for radical left parties is often seen as the product of their non-mainstream nature; they are seen as populist because they are anti-establishment, because they are illiberal, because they are nationalist.

The first approach is constructive and friendly towards the populist strategy on the radical left, while the second is critical and often dismissive. They both contribute to conceptual confusion, but each in a different manner. For the critical views, much has already been said here: it should perhaps be repeated that anti-populism is fierce and predominant in liberal discourse. Yet a positive view of left populism can also play into misrepresenting radicals, inasmuch as it is taken to suggest full agreement over constructing counter-hegemony, novelty or uniqueness. First, if many of the features of today's populist forces are novel, some of them at least come from the depths of the radical left's history: most importantly, the search for a 'people', an ingroup, a force of counter-hegemony, the inclusionary features of populism and the elitist framing of national capitalism. ${ }^{7}$ Second, even today, at the time left populism has acquired widespread use as a concept, the radical left is far from unanimous on the issue. Left populism has always been a contested way forward, often dividing socialists along ideological and strategic lines. Indeed, the 'populist' style of mobilisation as premised in all-inclusive formulas has been often accused of

7 One can cite multiple historical examples, but perhaps one of the closest to the typified populist frame comes from the French Communist Party (PCF), which in the early 1930s, in the spirit of the national frontist strategies across western Europe, had crafted the slogan 'union of the French nation against the 200 families and their mercenaries'. See Escalona (2019). 
reformism or opportunism. As James Petras has already explained concerning the 1970s left-wing parties in southern Europe,

the indistinctness of the slogans, in terms of specifying which class interests would benefit or be adversely affected, was considered by many in the Left as a clever electoral tactic to secure lower-class support without alienating the middle class. In the aftermath of the elections, the vagueness of the promises allowed several of the Socialist leaders to state that they had not in fact promised any radical social reforms and therefore were following the same political-economic trajectory traced out before the elections. The point is, however, that the plebiscitary character of the campaigns - the mass excitement in crowded plazas, the focus on the personal leaders, the emphasis on general slogans - transmitted the feeling that 'movements for change' were under way, without creating any context for serious critical public examination of programmatic issues (Petras 1984, 146).

It is important to underline that not all left-wing populism is consolidated by serious critical examination of policy pledges, and certainly not all of the radical left aligned behind populism in the period after the 2008 financial crisis or more generally in the 2000s. While some Trotskyist and other extra-parliamentary currents, for example, denounce post-Marxism and populism as its derivative strategy for undermining the prominent role of class and the labour-capital dichotomy in the development of society and the design of socialist strategy, others have participated in broad parties such as Die Linke in Germany, the Left Front in France and Podemos in Spain. Certain radical feminist critiques of populism pose that the latter is an obstacle to feminising politics, reinforcing patriarchal systems (Roth and Shea Baird 2017). The orthodox communists, such as the Greek (KKE) and Portuguese Communist Party (PCP) do not deviate from a strict and absolute class-based understanding of contemporary struggles, and neither does any party in Europe with the label of the communist or workers' party, no matter how small or large they are. Pointedly, some of the parties identified as representative examples of party populism, such as SYRIZA in Greece and Die Linke in Germany, themselves approach populism mostly as a smear from their enemies, as an ideological dispositif and not a positive selfdescription à la Podemos or France Insoumise.

The term is so widely misused and so adamantly utilised to stigmatise the left and align it with the far right that parties like SYRIZA and Die Linke may de facto voice populist rhetoric but certainly do not defend a populist strategy, which in their national-cultural contexts is synonymous to cheap and superficial politics, the politics of very many promises and no actions, as well as a key feature of extremist competitors. On the one hand, populism is embraced by revolutionaries and reformists, communists and Keynesians, partisans and activists, cutting across older divides. On the other, it is also either rejected en masse as a theory-informed discursive practice, or as a label, or still debated and scrutinised as a broader political strategy, depending on the organisation in question and its internal balance of power.

Conceptual confusion arises when the radical left is equated to the populist radical left, or when the latter implies the entire political space in question. Of course, this has political implications. If radical left forces are seen as coherently and above all else populist (which is why one would add the prefix 'populist' before mentioning them), then the problems facing the radical left may be reduced to those faced by the 
populist strategy writ large. Indicative of this verbal slippage, in a recent article for Jacobin, Anton Jäger titled his thoughts as follows: "We bet the house on left populism and lost it". He writes that by 2019 "short-lived and cruel, Europe's experiment in left populism had ground to a halt" (2019). Through this seemingly surprising observation, in his introduction the writer groups together the Greek moment of 2015, during the negotiations between SYRIZA and the EU concerning the bail-out, the 'Oxi' tweets, Paul Mason, Toni Negri, Stathis Kouvelakis, David Graeber, and the general feeling that an alternative might be coming. "Left populists want more than the whole cake", the author writes, "Instead, they have sought to seize the bakery itself - a far-reaching overhaul of the Eurozone, a departure from austerity programs, and an ambitious expansion of social provision" (Jäger 2019). But left populism doesn't explain or exclusively represent these positions. These are standard democratic socialist positions embraced by both left-wing populists and others who may be as different as staunch anti-populists. These positions united distinct ideological spaces within the left, carrying over from the classical socialist and social democratic tradition. They were there in the 1990s as well, put forward by parties such as the IU in Spain and Rifondazione Comunista in Greece. Given that ideology conditions discourse (Gerring 1999), the way these positions played out in political experience reflects mostly the challenges and limits of radical reformism in globalised and financialised neoliberal capitalism, and only then the discourse used to legitimise them.

Further, SYRIZA's capitulation to the demands of Greece's creditors in 2015 was not a defeat of left-wing populism. In fact it had nothing to do with left-wing populism but rather with SYRIZA's incapacity to offer an alternative and prepare for power, in conjunction with the Eurozone's internal dynamics and the authority of capital (Kouvelakis 2016). Hence, if the failure of radical visions to translate into policies is the issue here, then it is the radical left strategy in its totality that has failed and not only its populist parts, moments or dimensions. And if this is the case, then any recent limitations, challenges and mistakes concern much more the left and capitalism than merely left-wing populism, especially in the conjuncture of the multiple crises during the 2010s and into 2020. Accordingly, the left needs to turn its attention to the structural questions of politics, to complement them and not replace them with queries of language and the psycho-social responses to it.

The argument can also be reversed to consider populism as important for radical left victory. Positive approaches to left populism argue explicitly that it is a successful strategy. Venizelos and Stavrakakis (2020) synthesised a counter-critique to what they call left-wing anti-populism as follows:

In fact, without a populist mobilizing strategy, Syriza - and Podemos - would not have been in a place to either honor or betray its policy commitments, to start with; while Bernie Sanders would not have been able to popularize his social-democratic agenda in the United States either. Nobody would have heard about them, in the first place.

This is a bold statement. Yes, anti-establishment rhetoric is useful in the politics of opposition; yes, inclusiveness, sovereignty, popular appeals and images, commonsense arguments and so on also work, especially in today's ideational universe. But can we really strip down the success of SYRIZA in Greece or the success of Podemos to the political performance of a rhetorical strategy? Don't multiple questions arise that remain unaccounted for by convictions like that of the statement 
above? What about Greek neoliberalism in prompting SYRIZA to power? What about Podemos' lack of populist far right competition? What about the electoral defeats of Eurocommunist-type populism in the 1980s in Italy, France and Spain? What about the defeats of Popular Front strategies in France and Spain? Insofar as the defence of left populism implies linguistic determinism it can neither offer a full explanation of radical left resurgence, success or failure, nor account for the differentiated trajectories of populism across time and space. More explicitly, a left populist strategy is not always (equally) useful and needs to be approached more as a 'double-edged sword', whereby "It is ultimately up to the contexts, the stakes and the agents" how it is utilised (Charalambous and loannou 2019, 265).

\section{Reclaiming Radicalism}

A specific and unchanging number of things characterise the radical left and these are also the features which render other concepts used in polemic or analysis as either obsolete or epiphenomenal. Given that there is no universal accepted definition on radicalism, radical attitudes and the significations of root and branch change (Arzheimer 2011), radicalism has taken up meanings and associations which differ across countries and evolve through history (for a review, see Gordon and Kinna 2019, 4-6). Radicalism is both about positional distance (the far as opposed to the centre-left) and its interpretation. Or, as it has been alternatively phrased, "radicalism is equally about starting points, novelty and extremes" $(2019,4-6)$. In this sense the adjective 'radical' is to be understood not only as a relational signifier but also as a substantive one. After all, the centre, opposite which one is or is not a radical, can shift in substance, although not in name.

To reconcile substantive and positional understandings of the radical left, the positional distance between a radical and a centre-left can be seen as a more radical or subversive espousal of equality and also liberty and fraternity; as far as this effectively translates into anti-capitalism, draws from a broadly Marxist and critical influence and seeks systemic alternatives, whether through reform or insurrection. A radical left is thus left of the centre at a distance approaching the extreme end of the spectrum rather than the centre, but it is also an anti-capitalist left or a left critical of capitalism, seeking to turn emancipatory visions into practice. The radical left is not only a left broadly inspired by the socialist ideal, but its very radicalism is fuelled by its socialist heritage. It also reaches far in organisational format and mobilisation repertoires (intellectuals, trade unions, social movements, parties, militant research collectives, solidarity movements, churches and more), and is substantively a plural left, both in terms of ideas and structures. It is about reforms and extra-institutional action, verticality and horizontality, internationalism, the rights of oppressed communities, private and public sector workers, blue collars and white collars, immigrants, intellectuals, students, feminists, environmentalists, queers, indigenous people, anarchists and statists.

What reclaiming radicalism entails is reconstituting and capitalising on the centrality and importance of these defining features as opposed to the obsolete, divisive or epiphenomenal ones within the public sphere. This may appear as an explicitly rhetorical task, if not also a self-evident truth. In reality it entails a number of political imperatives:

- To deconstruct current understandings of, and reactions to, extremism, indicating the real extremisms (of the nominal centre) and uniting behind an understanding of them as such. Accordingly, it must be recalled that in many countries, the extreme 
right is a historical outgrowth, at some times a political breakaway and at others a collaborator of nominally centrist spaces. In this direction it is pertinent to maintain and defend positional distance and thus the advocacy of 'extreme measures' as today necessary for even the most basic aspects of the human condition; while fighting with full force extremism's anti-humanist and anti-democratic strain.

- To aim at disseminating radical framings of civil disobedience and attempt to strike a long-term equilibrium between social movements and politicians on this issue. This engenders the expectation, demand and promotion of social activism among radical left party politicians: that is to say, their solid and institutionalised fusion with the masses at every possible opportunity, as a way forward in dealing with personalistic and vertical political structures and bringing the militant left back into focus.

- To formulate and propagate visions of a better world, endorsing the search for utopias: in essence, to reacquire teleology. Without as tangible a plan as possible as to what the world should look like, ontological lines of distinction from other spaces can more easily be blurred in political discourse. It is thus important to consolidate utopian thinking in the collective radical imaginary, to speak away from the terminology of laissez-faire and through the concepts of critical political economy - scarcity and abundance, leisure as freedom, full employment, socialism as process, worker councils, collectivised production (see Gindin 2018).

- To draw clear lines of demarcation between anti-democracy on one side and emancipation through reconfiguring liberal democracy on the other side. This does not mean a total rejection of political liberalism but the root and branch change of liberal economic policies, which fuel the democratic deficits of politics.

- To effectively communicate the lens of internationalism, explicitly rejecting ethnic, cultural or other demographic particularism, either in what concerns the forces of production or beyond them. This means distinguishing with the utmost clarity the universality ingrained across all different traditions of the radical left, away from the particularism that extreme right nationalism and ethno-populism evoke. To achieve this demarcation of sides, although nationalism must be accepted as a progressive force where it exists that way, it cannot be a tool for claiming political legitimacy. In this vein, civic understandings of nationalism on the radical left must always be traced down to their founding stones - egalitarianism, anti-imperialism and anticapitalism.

- To avoid elevating the features of populist strategies above their historicity. Their status as a space within a space should be maintained as a given. Also, their contribution to the domain and field of anti-capitalist and progressive struggle can only be partial rather than holistic. Opposition to capitalism is much wider and more complex than populist stratagems can provide for as a politics of resistance.

- To constantly strive to claim a plural and inclusive people. For the radical left, this means above all to accept and effectively communicate the pluralism of its thought and practice, to turn it into a good thing rather than identify it as a vulnerability or lack of cohesion. Radicals should present such pluralism as a positive sign of multiple ongoing radical experimentations and evidence of democratic debate and deliberation across different ideological currents. Such diversity is also an indication that a socialist future can only be a pluralist one. Any divergences over teleology or strategy then must not a priori constitute lines of division. Rather the issue at hand is how to utilise political affinity; how distinct modes of mobilisation and ideological thinking can serve points of convergence on policy and political goals. 
Ontology and epistemology are interrelated, as established by the Kuhnian explanation of scientific revolutions. Reclaiming radicalism is inevitably a project that involves both discourse and action: it is a performance as much as it is a grounded practice. While radicals do best to engage with conceptual issues in the study and talk of the collective actors representing them, political behaviour will always feed back into terminology and the castigation of collective democratic and social struggles. In lieu of further elaboration between these two aspects of politics, let us summarise how: when electoral campaigns evoke national sovereignty simplistically and through sloganeering, nationalism resonates more easily as a defining feature of the left. When alliances occur with nationalist and right-wing forces, alleged affinities between the two parts of the alliance will gain face validity. Only if carefully balanced in electoral rhetoric and supported by radical programmatic positions and untarnished actions on the ground will socialism avoid taking 'the back seat' in questions of selfdetermination. For left populism, if the discursive strategy of constructing a counterhegemonic, sovereign people is aligned with the politics of personalised organisations or sectarianism, it is cancelled out. This is both because of the negation of the people's central role as a collective whole over individual identities and due to the fact that fragmentation is opposite of what left populism is about mass unity of a relatively heterogeneous crowd.

Similarly, when government participation (as in Italy and France during the late 1990 s, or Greece in the 2010s) leads to endorsing welfare retrenchment or foreign imperialist wars or austerity packages, the far right can more effectively claim an antiestablishment profile, a 'neo-socialist' or 'neither left nor right' identity; and the radical social milieu often becomes alienated. Political compromise becomes an important concept and the lines separating it from co-optation, de-mobilisation and selfnegation are thin. When radicals cease to be radical they face setbacks. And much of the aftertaste leads to divisions and sectarianism. This is in any case not an easy or temporary pathology to get rid of, given a broad, complex and rich ideological heritage. Moreover, to speak of socialism to promise a utopia and explicitly invoke transformative potential is perhaps the discursive tactic most in need of ontology. Without a solid, scientific, collective and rigorous background of policy elaboration and theoretical discussion, a discourse which brings teleology in from the cold without making the case for socialism's plausibility is exposed to all the common accusations dealt with here.

Any form of contradiction, disjuncture or incongruence within the radical left will eventually be discursively articulated into an offensive against it. This attack can either concern its false promises, oversimplifying pledges and thus demagogic style, or more generally its veritable continuity with other political forces, which engage in 'politics as usual'.

\section{Conclusion}

Reclaiming radicalism can be fuelled when collective efforts by popular and workers' movements, politicians and intellectuals are made to alter the existing dialectic between discourse and action. For this act of resistance to be fruitful, collective agency and a certain degree of unity, a famille spirituelle, are necessary. Consistency is also important, but both of these potentialities are influenced and often obstructed by historical time and national specificities, as well as the contingencies of elections and parliamentary structures. Distorting signifiers of left radicalism have come into widespread circulation because of pre-existing structural 
factors. Yet agency can either be present, or not. Reclaiming radicalism is a complex and difficult task to achieve, especially in the age of fake news and given that the radical left political space as a whole is fragmented. Yet doing so is visibly pertinent in the battle of ideas and interest if radicals want to compete and struggle on their own terms and not those of others.

Finally, inasmuch as the left needs to plan specific strategies to deal with systemic labelling and the discursive distortion of its identity, there is also a grave need to decipher strategic success and failure in doing so thus far. Further study in this direction will be most effective if it is both conceptual and empirical: that is, simultaneously identifying how discourse can be legitimised or delegitimised by action, and how this effect has operated in particular historical eras and instances.

\section{References}

Abedi, Amir. 2009. Anti Political Establishment Parties: A Comparative Analysis. London: Routledge.

Anderson, Benedict. 2006. Imagined Communities: Reflections on the Origin and Spread of Nationalism. London: Verso.

Agustín, Oscar Garcia. 2020. Left-Wing Populism: The Politics of the People. Bingley: Emerald Publishing.

Ali, Tariq. 2015. The Extreme Centre: A Warning. London: Verso.

Arzheimer, Kai. 2011. Radical Attitudes. In International Encyclopedia of Political Science, edited by B. Badie, Dirk Berg-Schlosser, and Leonardo Morlino, 2199-2202. London: Sage.

Backes, Uwe. 2010. Political Extremes: A Conceptual History from Antiquity to the Present. London: Routledge.

Backes, Uwe and Patrick Moreau, eds. 2008. Communists and Post-Communists in Europe. Gottingen: Vandenhoeck and Ruprecht.

Bruff, Ian. 2014. The Rise of Authoritarian Neoliberalism. Rethinking Marxism 26 (1): 113129.

Charalambous, Giorgos and Gregoris loannou. 2019. Conclusions: Populism and left radicalism in Europe across time. In Left radicalism and Populism in Europe, edited by Giorgos Charalambous and Gregoris loannou, 257-26. London: Routledge.

Charalambous, Giorgos and Panos Christoforou. 2018. Far-Right Extremism and Populist Rhetoric: Greece and Cyprus during an Era of Crisis. South European Society and Politics 23 (4): 451-477.

Conversi, Daniele. 2017. The Left and Nationalism: Introducing the Debate. H-Net: Humanities and Social Sciences Online. Accessed 23 December 2020. https://networks.hnet.org/node/3911/discussions/588345/left-and-nationalism-monthly-series-left-andnationalism

Escalona, Fabien. 2019. Social democracy and the temptation of populism between the world wars: France in a comparative perspective. In Left radicalism and Populism in Europe, edited by Giorgos Charalambous and Gregoris loannou, 257-265. London: Routledge.

Gellner, Ernest. 1983. Nations and Nationalism. Ithaca: Cornell University Press.

Gerbaudo, Paolo. 2017. The Mask and the Flag: Populism, Citizenism and Global Protest. London: Hurst Publishers.

Gerring, John. 1999. Ideology: A Definitional Analysis. Political Research Quarterly 50 (4): 957-994.

Gindin, Sam. 2018. Socialism for Realists. Catalyst 2 (3). Accessed December 7, 2020. https://catalyst-journal.com/vol2/no3/socialism-for-realists

Golder, Matt. 2016. Far Right Parties in Europe. Annual Review of Political Science 19 (1): 477-497. 
Gordon, Uri. and Ruth Kinna. 2019. Introduction. In Routledge Handbook of Radical Politics, edited by Ruth Kinna and Uri Gordon. London: Routledge.

Hobsbawm, Eric. 2007. Revolutionaries. London: Abacus.

Hobsbawm, Eric. 1996. Identity Politics and the Left. New Left Review 217: 38-47.

Hobsbawm, Eric and Terence Ranger, eds. 1983. The Invention of Tradition. Cambridge: Cambridge University Press.

Jäger, Anton. 2019. We Bet the House on Left Populism - And We Lost. Jacobin, November 25. Accessed April 15, 2020. https://jacobinmag.com/2019/11/we-bet-the-house-on-leftpopulism-and-lost

Kallis, Aristotle. 2018. Populism, Sovereigntism, and the Unlikely Reemergence of the Territorial Nation-State. Fudan Journal of the Humanities and Social Sciences 11: 285302.

Kallis, Aristotle. 2015. When Fascism Became Mainstream: The Challenge of Extremism in Times of Crisis. Fascism 4: 1-24.

Katsambekis, Giorgos and Alexandros Kioupkiolis. 2019. Preface. In The Populist Radical Left in Europe, edited by Giorgos Katsambekis and Alexandros Kioupkiolis, xi-xii. London: Routledge.

Keskinen, Suvi, Ov Cristian Norocel and Martin Bak Jørgensen. 2016. The Politics and Policies of Welfare Chauvinism under the Sign of the Economic Crisis. Critical Social Policy 36 (3): 321-329.

Kouvelakis, Stathis. 2020. The "Crisis Of Marxism" and the Post-Marxist Moment. In Routledge Handbook of Marxism and Post-Marxism, edited by Alex Callinicos, Stathis Kouvelakis and Lucia Pradella, 337-350. London: Routledge.

Kouvelakis, Stathis. 2016. Syriza's Rise and Fall. New Left Review 97: 45-70.

Lipset, Seymour Martin. 1958. Social Stratification and "Right-Wing Extremism". The British Journal of Sociology 10 (4): 346-382.

March, Luke. 2008. Contemporary Far Left Parties in Europe: From Marxism to the Mainstream? Berlin: Friedrich-Ebert-Stiftung. Accessed October 10, 2020. http://library.fes.de/pdf-files/id/ipa/05818.pdf

March, Luke and Cas Mudde. 2005. What's Left of the Radical Left? The European Radical Left After 1989: Decline and Mutation. Comparative European Politics 3 (1): 24-25.

Mair, Peter. 2013. Ruling the Void: The Hollowing of Democracy in the West. London: Verso.

Meiksins-Wood, Helen. 1986. The Retreat from Class: A New True Socialism. London: Verso.

Mondon, Aureliene 2014. The Front National in the Twenty-First Century: From Pariah to Republican Democratic Contender? Modern \& Contemporary France 22 (3): 301-320.

Mudde, Cas. 2004. The Populist Zeitgeist. Government \& Opposition 39 (4): 541-63.

Oesch, Daniel. 2008. Explaining Workers' Support for Right-Wing Populist Parties in Western Europe: Evidence from Austria, Belgium, France, Norway, and Switzerland. International Political Science Review 29 (3): 349-373.

Oppenheim, Maya. 2017. Noam Chomsky: Antifa is a Gift to the Far Right and US State Repression. The Independent, December 10. Accessed August 20, 2020.

https://www.independent.co.uk/news/world/americas/noam-chomsky-antifa-us-alt-right-usstate-donald-trump-white-nationalist-a8044526.html

Petras, James. 1984. The Rise and Decline of South European Socialism. New Left Review I/146: 37-52.

Pickel, Andreas. 2003. Explaining, and Explaining with, Economic Nationalism. Nations and Nationalism 9 (1): 105-127.

Rosas, Joa o Cardoso and Ana Rita Ferreira, eds. 2013. Left and Right: The Great Dichotomy Revisited. Newcastle upon Tyne: Cambridge Scholars Publishing.

Roth, Laura and Kate Shea Baird. 2017. Left-wing Populism and the Feminization of Politics. ROAR, January 13. Accessed April 15, 2020. https://roarmag.org/essays/leftpopulism-feminization-politics/ 
Rydgren, Jens, ed. 2013. Class Politics and the Radical Right. London: Routledge.

Schedler, Andreas. 1996. Anti-Political-Establishment Parties. Party Politics 2 (3): 291-312.

Schwarzmantel, John. 2012. Rethinking Marxism and Nationalism in an Age of Globalization. Rethinking Marxism 24 (1): 144-161.

Sears Alan. 1999. The "Lean" State and Capitalist Restructuring: Towards a Theoretical Account. Studies in Political Economy 59 (1): 91-114.

Seferiades, Seraphim and Hank Johnston. 2016. The Dynamics of Violent Protest: Emotions, Repression and Disruptive Deficit. In Violent Protest, Contentious Politics, and the Neoliberal State, edited by Seraphim Seferiades and Hank Johnston, 3-18. Farnham: Ashgate.

Smith, Anthony. 1999. Myths and Memories of the Nation. Oxford: Oxford University Press.

Smith, Anthony. 1995. Nations and Nationalism in a Global Era. London: Wiley.

Tarrow, Sidney 1998. Power in Movement: Social Movements and Contentious Politics. Cambridge: Cambridge University Press.

Unger, Roberto Mangabeira. 2009. The Left Alternative. New York: Verso.

van Prooijen, Jen Willem and André P. M. Krouwel. 2019. Psychological Features of Extreme Political Ideologies. Current Directions in Psychological Science 28 (2):159-163.

Venizelos, Giorgos and Yiannis Stavrakakis. 2020. Left-Populism is Down but Not Out. Jacobin, 22 March. Accessed November 20, 2020. https://jacobinmag.com/2020/03/leftpopulism-political-strategy-class-power

Vilallonga, Boaz. 2015. The Catalan Left: An Interview with Boaz Vilallonga. Jacobin, 18 October. Accessed December 20, 2020. https://www.jacobinmag.com/2015/10/catalanreferendum-spain-podemos-independence/

Vössing, Konstantin. 2011. Social Democratic Party Formation and National Variation in Labour Politics. Comparative Politics 43 (2): 167-186.

\begin{abstract}
About the Author
Giorgos Charalambous

Giorgos Charalambous is Assistant Professor of Political Science at the University of Nicosia, working in the field of comparative European politics and political sociology and especially focusing on parties, ideas, attitudes and mobilisation processes. He is currently the co-convenor of the Left Radicalism Specialist Group (sg) of the Political Studies Association (PSA). His second monograph 'The European Radical Left: Movements and Parties since the 1960s' is forthcoming with Pluto Press.
\end{abstract}

